\title{
The Change in the Original Plan \\ for Marx's Capital and Its Causes
}

Henryk Grossman

As remarkable as it may seem, the set of problems concerning the structure of Marx's chief work, as well as its relation to Theories of Surplus Value, on the one hand, and to the earlier publication $A$ Contribution to the Critique of Political Economy, on the other, has never been the subject of an investigation. One can scarcely find another book that has shaped a whole century to the same extent, theoretically and practically, and which, despite its enormous importance, has been treated with a greater indifference with regard to its form, the history of its genesis and the logic of its structure!

It would be superfluous to speculate here about the reasons for the unsatisfactory state of research on Marx. Suffice it to say that - despite all the discussions about Marx that we have gone through over the past three decades, in the advanced capitalist countries of Europe - we still find ourselves only at the start of scientific research on Marx. Only the publication of Marx's works announced by the Marx-Engels Institute in Moscow will decisively change this situation. ${ }^{1}$

Regardless, it would be an inexcusable relapse into the mistakes of historicism to remain theoretically inactive until such a time. On the contrary, the following investigation attempts to critically evaluate the problem encompassed in the title on the basis of already-known source materials and to demonstrate that important insights can be gleaned from them.

The problem that arises here is twofold. The first concerns the preliminary question whose answer must precede any scientific analysis of Marx's thought, the question of the completeness of the materials that have come down to us. That is, whether Capital, as it exists now - including Theories of Surplus

\footnotetext{
* [Originally published as Grossmann 1929b. This essay has been prepared for the four-volume Henryk Grossman: Selected Works project, to be published in the Historical Materialism book series. Footnotes in square brackets have been added by the editor.]

1 [Grossman refers to Marx and Engels 1927-41, initially published under the direction of David Riazanov, twelve of whose planned 42 volumes appeared between 1927 and 1941 when the project was killed off by Stalin's regime, as many of its German and Russian editors had been.]
} 
Value - essentially comprises the whole thing, apart from individual gaps in its elaboration. Whether, consequently, Capital constitutes a complete system or whether we are dealing here with fragments of a larger work. The second, the real problem, concerns the methodological viewpoints, which were decisive working up the material, in the arrangement of the work and in the organisation of its elements. Both problems, it will be shown, stand in close relation to each other.

The first problem, of course, could only arise from the fact that Marx himself could only supervise the publication of the first volume; that the remaining volumes were published by Engels from the manuscripts left after Marx's death, and, insofar as they dealt with the theories of surplus value, by Kautsky; that the history of the origins of this work, reckoned from 1859, the publication date of $A$ Contribution to the Critique ${ }^{2}$ the first treatment of the opening chapter of Capital, comprises a period of a half-century.

It is indicative of how little these problems have been considered that, on the question of the completeness of the existing materials, a cardinal and obvious preliminary question for all analysis of Marx, there prevails the most hair-raising lack of clarity, as the crassest example of which I want to cite the views expressed by Robert Wilbrandt. We know the material Marx wanted to deal with from the Preface to A Contribution to the Critique (1859), where the original plan for the work was specified: 'I examine the system of bourgeois economy in the following order: capital, landed property, wage-labour; the state, foreign trade, world market. ${ }^{3}$ The sequel to the original work, as it exists in the three volumes of Capital, however, followed another plan. Already in 1897, on the occasion of the new edition of $A$ Contribution to the Critique, Kautsky wrote: 'Thus, the construction of Capital differed from that of the work whose first section was published by Marx in 1859. This is proved by a glance at the first lines of the Preface to the Critique and a comparison of the plan developed there with that actually followed in Capital.'4 And although this can already be seen at a 'first glance', the fact of the change in the plan for Marx's Capital escapes Professor Wilbrandt, despite his many bows toward this 'extraordinary work', which, so to speak, he is officially duty bound to make, as author of his own 
book on Marx. After going into the history of the genesis of the work and the original plan of 1859, the plan for a work of six parts, he then instructs the world that the only volume of Capital that Marx himself published has remained a torso in a double sense. Not only, firstly, because it is 'only the first of many volumes', but, secondly, 'it is only the first volume of a work that itself is part of a whole: the first of six parts of the whole work that the author envisaged would treat many problems, which he intentionally refrained from considering in the first part, in Capital, so as to reserve them for the later parts. ${ }^{5}$ According to this fantastic account, the four volumes of Capital that we have turn out to be merely the implementation of the first part of the plan of 1859, which was to be followed by another five parts! Consequently, Marx's currently available work is considered only a small fraction of a planned work that should perhaps provide just as comprehensive accounts of ground rent, wage labour, foreign trade, etc. as those on capital. So, altogether, perhaps a further twenty volumes and indeed dealing with cardinal areas, without knowledge of which what has already been said about capital, torn out of the context of the whole, would also necessarily be difficult to understand.

We must counterpose a question to this account: is it correct that Marx 'consciously refrains' from considering these problems in Capital; that he only intended to deal with the questions of ground rent, wages and foreign trade later? Apparently Wilbrandt has not noticed the analysis of all these questions in Capital. He takes the opportunity of Marx's theory of wages to highlight an alleged gap and maintains that an 'elaboration could well have been hoped for in the part on wage labour; ${ }^{6}$ as though Marx had not dealt completely enough with and clarified his theory of wages in Capital!

Wilbrandt's ignorance of the most elementary facts in his subject area should not have prevented him from being aware of the modification of the original plan for Capital. Not only because this modification can been seen 'at first glance' and had already been observed by Kautsky, but because Marx himself - as we are instructed in his correspondence with Kugelmann - emphatically confirmed it.

From the new draft plan, which he tells Kugelmann about and which we cite further below, it is clear to see that Capital, as it is presently available to us in four volumes, is essentially complete. In the available volumes, even though the exposition in the individual sections has gaps in places, a chapter may be missing here and there, and the logical sequence is often interrupted, on the whole not only is all of the material to be dealt with included, but at the 
same time, as Engels said, 'what Marx intended to say is said there, in one way or another'. ${ }^{7}$ This can also be seen particularly in the important letter Marx wrote to Engels on 30 April 1868 in which Marx tells his friend about the content of the second and third volumes in detail, and essentially enumerates the order and treatment of the material as we find it again later in the two volumes of Capital that Engels took care of. ${ }^{8}$

The example of Wilbrandt demonstrates best how the most confused views prevail, even about matters like the problem of the external structure of the material in Capital, which belongs among the preliminary questions for all analysis of Marx. Is it any wonder, then, that the internal structure of the work, the underlying methodological problems and solutions, which present real difficulties, is absolutely unclear?

\section{II}

If we now turn our attention to the actual object of our analysis and ask why the original plan for Capital was changed, we must emphasise that, so far, this decisive, cardinal question for the comprehension of Marx's work not only remains to be clarified, but has not even been posed! Strangely enough, people were satisfied with the statement of the facts, as was e.g. Kautsky; the 'why' was never investigated.

Understandably, Kautsky's indifference to such fundamental theoretical problems derives from his whole attitude towards Marx's principal work. According to Kautsky, 'Capital is essentially an historical work'! ${ }^{9}$

It is self-evident that a change in the plan for Capital really could not possibly be a matter of chance or a technical question of presentation, e.g. of clear arrangement, but must obviously have been the result of careful consideration and compelling reasons. This supposition appears all the more irrefutable, as one is unlikely to be inclined to undertake a change in the construction of a work, whose first part has already been published, and that was - as Marx said in the 1859 Preface - 'the outcome of conscientious research carried out over many years. ${ }^{10}$ Marx had been intensely occupied with studies in political economy since his anti-Proudhon, written in $1847 .{ }^{11}$ What, then, moved Marx after sixteen years of untiring research, despite the successful publication of

7 Engels 1978, p. 86. [Grossman's emphasis.]

8 Marx 1987f, p. 20.

9 Kautsky 1921, p. viii. [Grossman's emphasis.]

10 [Marx 1987a, p. 265.]

11 [Marx 1976a.] 
the first part of his work in 1859, to revise his work anew, which would obviously have to result in a new delay in its completion?

Now, if it is true that the slow progress of the work - after the appearance of A Contribution to the Critique - was a consequences of several unfavourable external causes, which Marx enumerates in the Preface to Capital and in the letter to Kugelmann of 28 December 1862 (years of chronic illness, being overwhelmed by other work), these circumstances could only explain the delay in the completion of the work, but not the change in the original plan. This consideration demonstrates to us that certain compelling internal grounds must have contributed to the change in plan. Indeed, Marx had already written to Kugelmann on 28 December 1862 that 'The second part has now at last been finished, i.e. save for the fair copy and the final polishing before it goes to press'. ${ }^{12}$ The words 'the second part' indicate that, at that time, on 28 December 1862, Marx was still working according to the original plan of 1859. Thus he still thought of it as the sequel to the 'first part', published under the title $A$ Contribution to the Critique. The work was to encompass about 30 printer's sheets and would appear soon.

On 29 November 1864, however, almost two years later, Marx informs Kugelmann that he hopes that his book on 'capital' will 'at last be ready for publication next year. ${ }^{, 13}$ In the intervening time since the letter of 28 December 1862 , the already completed work was not polished and neatly copied out; it was, rather, reworked and extended. Its size doubled and it grew to 60 sheets. And a further year elapsed before Marx - at the beginning of 1866 - could begin the fair copy of the first volume of Capital.

Consequently, if Marx's work was already 'complete' at the end of 1862 and ready for final polishing, and was nevertheless reworked in the following two years, one must conclude that difficulties arose in the course of work, which led to the necessity of revision and the change in the plan for the work. The profound fact of the change in the plan, which had implications for the fate of the whole work, occurred between 28 December 1862 and 29 November 1864.

But we can specify the decisive point in time of the change in the plan more exactly: as is apparent from the correspondence with Kugelmann, it was carried out in the second half, namely July-August, of $1863 .{ }^{14}$

The nature of the difficulties, which led the implementation of the original plan of 1859 to fail, and the methodological considerations that compelled the 
change in the plan for the structure of the work, can be identified by comparing the original plan of 1859 with the plan that Marx actually followed in Capital and had already announced in the letter to Kugelmann on 13 October 1866. Precisely there, Marx told his friend that the whole work would break down into the following parts:

Book I: The process of production of capital.

Book II: The process of circulation of capital.

Book III: Structure of the process as a whole.

Book IV: On the history of the theory. ${ }^{15}$

The difference between the two plans springs to the eye. While, in the plan of 1859, the work was to be comprised of six parts and was to be considered from the standpoint of the material - capital, ground rent, wage labour, foreign trade, etc. - the final plan of 1863 was organised from the standpoint of knowledge [Erkenntnis]. Out of knowledge-based methodological considerations, the individual functions of industrial capital carried out during its circuit - the production process, the circulation process, the process as a whole - are abstracted in thought and presented separately, regardless of the material. Only within the presentation of each of these functions is the whole material dealt with from the respective functional standpoints. ${ }^{16}$

As Engels discloses in the Preface to the second volume [of Capital, the first draft of Capital, written from 'August 1861 to June 1863', was still 'the continuation of the volume ... published in Berlin in 1859.' Conforming to the original plan, 'The themes dealt with in Volume 2, however, as well as the many treated later in Volume 3, are not yet grouped together. They are dealt with in passing.' The following are mixed up and treated together with material that is discussed in Volume 1, 'capital and profit, rate of profit, merchant's capital and money capital, i.e. themes that were later developed in the manuscript for volume 3. ${ }^{, 17}$

15 Marx 1987c, p. 327.

$16 \mathrm{E.g}$. in the production process: productive capital and the wage relation; commodity capital, the production of surplus-value both in industry and in agriculture, etc. In the circulation process: the turnover time of productive capital and of money capital; the turnover of the individual constituents of industrial capital, of its fixed and circulating parts, of its variable part and its surplus-value. In the process as a whole: the reproduction and circulation of total capital, both in industry and in agriculture, encompassing capital as well as the wage relation, division of surplus-value into profit, interest, rent, trading profit, etc., equalisation of profit to the average profit, money capital, commodity capital, etc.

17 Engels 1978, p. 84. [Grossman's emphasis. In the original the reference is, mistakenly, to the Preface of the third volume of Capital rather than the second.] 
Thus in Engels's account we also find confirmation of what emerged from the comparison of the Preface of $A$ Contribution to the Critique with the plan for Capital, as well as the analysis of the correspondence between Marx and Kugelmann: the first draft of Capital is organised according to the empirical material dealt with. Only a later draft, begun in the second half of 1863 , sorted the variegated material, confusingly mixed together, according to the specific functions of the circuit of capital. That a methodological turn of decisive importance took place in this way is now perfectly clear. The problem that now arises is synonymous with the question: what provoked this shift? Everything suggests that it stands in the closest connection with the discovery of Marx's reproduction schema.

The external connection is readily apparent: until June 1863 the work was developed according to the original plan of 1859. On 6 July 1863, Marx sent his friend the first draft of the reproduction schema, with which he wanted to replace Quesnay's tableau économique. ${ }^{18}$ Already in the letter of 15 August we hear further that Marx 'had to demolish everything'. The plan change appears here as an already accomplished fact. In this way, i.e. through the chronological course of events, the relation between the change in plan and externally the conception of the reproduction schema appears very probable. It is the task of the following presentation to demonstrate that not only an external, but also a necessary internal connection exists between the change in the plan for Marx's work and the methodological construction of the reproduction schema. The methodological perspective actually followed in the structure of Capital - the arrangement of the empirical material according to the functions which capital performs in its circuit consequently the change in the original plan of 1859 necessarily resulted from the way Marx formulated the question. As I have shown in other places, however, this question is, 'since the production of exchange value - the increase of exchange value - is the immediate aim of capitalist production, it is important to know how to measure it. ${ }^{19}$ The problem consists in the exact determination of the variations in the magnitude of surplus value in the course of accumulation, that is, in the establishment of how much surplus value a given capital can yield in its circuit.

If we formulate the problem in this way and take it as the starting point for our analysis, we can readily appreciate that the analysis of the capitalist mode of production according to the empirical material about individual, partial areas capital, ground rent, credit, foreign trade, wage relations, etc. - would necessarily fail in the face of insurmountable difficulties. Further, Marx

18 Marx 1985b.

19 Grossmann 1992, p. 61. 
nowhere commented on how he came to his ingenious conception of the reproduction schema. We are therefore compelled to reconstruct his train of thought from the conditions of the problem. ${ }^{20}$

Let us assume a given Capital I, e.g. of one million marks, which is invested in the textile industry. The question is: under the prevailing, exactly circumscribed conditions, how big is the surplus value realised by this capital? Initially, this problem appears to be uncomplicated. If the number of workers employed, the level of the rate of surplus value, the length of the working period and the turnover time are known, then the magnitude of yearly surplus value due is easily calculable. Upon closer examination, however, great difficulties soon appear. We know that during the circuit of capital, thanks to the specific conditions of the turnover mechanism, namely due to the inequality of the working and circulation periods, 'part of the capital successively advanced is set free. ${ }^{21}$ The entrepreneur does not leave this redundant capital lying idle but will temporarily lend it to the banks or invest it in easily realisable securities with a fixed rate of interest, ${ }^{22}$ and so secures the enjoyment of interest, that is, surplus value. If the capital set free in our example amounts to 80,000 marks and is lent out for six months at a rate of $8 \%$, the interest gained will amount to 3,200 marks. From what source was this interest obtained? Obviously not from the Circuit of Capital I, invested in the textile industry. Rather, these 80,000 marks, set free from the Circuit of Capital I, were withdrawn. They were, through the mediation of the bank, e.g. lent out to an iron producer and included in the Circuit of Capital II, invested in the iron industry. Capitalist I, the textile manufacturer, increased his total surplus value by 3,200 marks through credit intermediation. But this additional surplus value does not

20 Rosa Luxemburg's claim that, with respect to the reproduction schema, Quesnay can be considered Marx's sole predecessor, is incorrect (Luxemburg 1951, p. 31). I have demonstrated elsewhere that Sismondi's reproduction schema forms an historical and logical link between Quesnay and Marx. Commensurate with the superior development of the capitalist mode of production in Sismondi's time compared to Quesnay's in the middle of the eighteenth century, Sismondi introduces significant improvements into Quesnay's table. The independent producers [classe stérile] disappear, the class contradiction between entrepreneurs and wage labourers is stressed everywhere, the production of means of consumption is divided into that of necessities and luxuries, etc. (Grossman 1924, p. 14).

21 Marx 1978, p. 355. Marx demonstrates how the circuit of industrial capital is temporarily interrupted and accompanied by other forms of hoarding: because the amortisation fund of fixed capital is accumulated gradually until it is large enough to replace the fixed capital used up in the interim; because surplus-value is insufficient to function independently and therefore must be hoarded until it reaches 'the minimum magnitude required for it to function actively', Marx 1978, p. 163; or, finally, because parts of circulating capital earmarked for the purchase of raw materials or labour power are also temporarily hoarded (on hoarding, cf. Marx 1987a, p. 379).

22 Marx 1978, p. 164, and Marx 1981, p. 594 et seq. [The latter pages do not seem directly relevant, unlike p. 528.] 
originate in the Circuit of the advanced Capital I, but was obtained because the hoard of money, that came out of the Circuit of the industrial Capital I originally invested, performed 'particular capital functions outside the circuit of the industrial capital from which it arose. ${ }^{23}$ The additional surplus value of 3,200 marks was not produced by workers in the textile industry but by workers in the steel industry through the detour of credit intermediation. Had Marx adhered to the original plan for treatment according to the material, without separating out the individual functions of capital, he would have tangled himself up in irresolvable contradictions. In empirical reality, the circuits of various capitals intersect; so the exact answer to the question posed by Marx, about the magnitude of surplus value that a given capital can obtain, would be impossible without the application of the method of isolation. For a clear solution to the problem it was thus necessary to hold apart the two intersecting circuits of capital, i.e. to isolate Circuit I in thought, by first abstracting it from Circuit II and thus from credit. So we can understand why Marx was forced, by the inner requirements of the problem, to work with simplifying assumptions.

What has just been said about credit applies equally to foreign trade. From a domestic Capital I, advanced in e.g. the textile industry, a surplus value of a magnitude $y$ is due, if the commodities - according to Marx's assumption - are sold at prices equal to their values. Now, Marx has shown ${ }^{24}$ that in foreign trade commodities are not sold at their values; that here no equivalents are exchanged; that in fact the law of value in foreign exchange, in its international application, is thereby modified; that countries with a higher level of capitalist development exploit the less economically developed countries, 'so that the more advanced country sells its goods above their value... The privileged country receives more labour in exchange for less. ${ }^{25}$

It is now readily apparent that, for this reason, Marx's problematic, the question of the magnitude of surplus value that can be produced by a given capital, necessarily had to be obscured. For, through the sale of the commodities, e.g. textiles at prices above values abroad, an additional surplus value was obtained from the originally advanced Capital I, along with the normal surplus value. But this additional surplus value was not produced by workers in the domestic textile industry; rather this additional surplus value was created by workers abroad and was then transferred to capitalist I, by way of unequal exchange. In empirical reality, the process of production of Capital I intertwines with its process of circulation. Thus, to provide an exact answer to Marx's question - how much surplus value can a definite Capital I

23 Marx 1978, p. 164. [Grossman's emphasis.]

24 Grossmann 1992, p. 170.

25 [Marx 1981, p. 345. Grossman's emphasis.] 
produce? - possible, in order, so to speak, to maintain the sphere of production in a chemically pure state, Marx had to isolate the sphere of production from the disturbing influences of the sphere of circulation. The exclusion of the sphere of circulation and the consequent change in the magnitude of surplus value obtained by the originally advanced capital occurs as a result of the simplifying assumption that commodities in foreign trade are sold at their values. For, as a result of this assumption, sale at prices above values and thus the augmentation of surplus value that can be obtained domestically by means of the transfer of additional surplus value from abroad are excluded. Since values exchange for equal values, the change in the magnitude of value, and hence also the magnitude of surplus value, as a result of the disrupting influences of foreign trade, is impossible. Only now can the analysis of the surplus value that can be produced by a given capital take place in an exact way. Only in this context can we understand why Marx arrived at his assumption of 'normal' reproduction, of the sale of commodities at their values.

If normal annual reproduction on a given scale is presupposed, then it is also supposed ... that foreign trade replaces domestic articles only by those of other use or natural forms, without ... affecting the value ratios ... Bringing foreign trade into an analysis of the value of the product annually reproduced can therefore only confuse things, without supplying any new factor either to the problem or to its solution. We therefore completely abstract from it here. ${ }^{26}$

Marx's procedure is nothing more than the application of the procedure of isolation to the process of surplus-value creation, in order to obtain it in its pure form. 'The physicist,' says Marx,

either observes natural processes where they occur in their most significant form, and are least affected by disturbing influences, or, wherever possible, he makes experiments under conditions which ensure that the process will occur in its pure state ... In the analysis of economic forms neither microscopes nor chemical reagents are of assistance. The power of abstraction must replace both. ${ }^{27}$

That is, the real experiment of natural science must be replaced by the thoughtexperiment in economic research, in order to maintain in pure form the functions to be investigated, unclouded by disturbing influences.

Elsewhere I have shown that, just as Marx was forced here to put aside the modifications of the magnitude of value through foreign trade, he also had to abstract from the movements of price within a capitalism conceived 
of as isolated. For changes in price present themselves as deviations of prices from values, where price increases on one side of society correspond to price decreases on the other side and thus cancel one another out. The task Marx set himself, the exact measurement of the additional surplus value over the initial magnitude of capital advanced, necessarily led him to the exclusion of this type of change in price. For he was only interested in the real change in value, i.e. the growth of surplus value, the increase in exchange value. In contrast, fluctuations of price are deviations from the median line of value, the result of the fluctuating configuration of supply in relation to demand. The magnitude of value, however, is not modified by changes in the relation of supply and demand. Therefore, from the standpoint of his formulation of the problem, Marx had to abstract from these changes. Thus he necessarily arrives at the assumption of equilibrium as a starting point for his analysis, where supply and demand exactly balance; hence prices coincide with values. As earlier for foreign trade, so now the assumption holds domestically that commodities are sold at their values. ${ }^{28}$

And, as a result of the same considerations, Marx arrived at a further simplifying assumption. In order to be able to determine the influence of changes in the productivity of labour on the creation of surplus value, he was forced to carry out the investigation on the assumption that the value of money did not change. The purpose was to obtain an exact yardstick for the determination of the movements of the value of industrial capital during its circuit. ${ }^{29}$ For, if the value of money varied, it would be difficult to determine whether growth in the value (price) of commodities is only apparent, merely arising from a change in the value of money.

We have, therefore, demonstrated how Marx, through the requirements of his problematic, necessarily came to take not the immediately given world of appearances as the object of his analysis, but to work with a series of simplifying assumptions: instead of organising his analysis according to the empirically given material, according to partial areas (capital, foreign trade, etc.), he abstracts from credit, from competition, from foreign trade and assumes that the value of money is constant. In short, it was demonstrated how he comes to describe the particular functions of capital instead of the particular material areas; e.g. firstly the process of production of surplus value and subsequently the function of circulation, i.e. the transfer of surplus value. Only by the complicated means of isolating and examining the functions of capital, one at a time, was Marx in a position to explain the actually obtained, 
empirically given expansion of capital, i.e. to analyse exactly the sources from which it originates.

But the series of simplifying assumptions was not exhausted by the considerations already mentioned. The other simplifying assumptions that resulted from his problematic meant that Marx could not start with the empirically given partial forms of income without labour: industrial profit, interest, ground rent, merchant's profit, etc. He had, rather, to use their ideal aggregate in the common, fundamental form of surplus value, as the distinctive category of his analysis. For, to start with, the division of surplus value among particular groups of capitalists did not interest Marx. Instead, what interested him was the problem of surplus value itself, the magnitude of surplus value that could be obtained and its variations, i.e. its developmental tendencies, in the course of capital accumulation. If taxes are high, then the portion of surplus value remaining for the capitalists is smaller. If the interest rate is low, then the portion of surplus value remaining for the industrial and merchant capitalists, etc. is larger. The total magnitude of the surplus value originally produced is not altered by changes in the division of surplus value among the state, the banks, the industrialists, etc. From the standpoint of his problematic, Marx thus had to put aside the specific forms into which the surplus value is divided. For this reason, however, adherence to the original plan of 1859 was impossible. Where it is a matter of the total magnitude of surplus value, how could capital and ground rent now be treated as separate subject areas? After all, ground rent is merely a part of surplus value. In this way, under the compulsion of his problematic, Marx had to give up the treatment according to separate subject areas. Instead of the analysis of the empirically given subject areas - interest, rent, merchant's profit, etc. - he had to place the function of surplus-value creation in the foreground; i.e. he had to make the process of production the chief object of analysis. For this is at the same time the process of surplus-value production. Thus surplus value is grasped at its source, before its division into its component forms, which immensely facilitates the analysis of the magnitude of surplus value in its totality; in fact, makes this possible. 'On the other hand', says Marx, 'we treat the capitalist producer as the owner of the entire surplus value ... as the representative of all those who will share the booty with him ... The break-up of surplus value into various fragments does not affect either its nature or the conditions under which it becomes an element in accumulation. ${ }^{30}$

Methodological implications of utmost importance for further investigation follow from this assumption. For, to begin with, the classes of landlords, big and 
small merchants, state officials who live from taxes, etc., i.e. all parasites, those who share in the surplus value, thus, those classes that are not involved in the production of surplus value, had to be set aside from the analysis. The whole analysis had to be reduced to the fundamental contradiction in the production of surplus value: capitalist class-working class.

Finally, it is also clear from Marx's formulation of the problem why the independent producers, farmers and artisans, had to be set aside from the analysis. Marx wanted to investigate the capitalist process of surplus-value production, i.e. capitalism in a 'chemically pure' form, free of impure admixtures of non-capitalist formations. For it would otherwise not be possible to determine the exact extent to which the result of the analysis is attributable to the capitalist elements or to the non-capitalist elements blended with them. In order to obtain such a 'chemically pure' capitalism, Marx had to limit his analysis to the classes that constitute the specific character of the capitalist mode of production, the capital relation, while demonstrating that independent producers are the remnants of earlier economic formations and therefore remain outside the capital relation. In this way, Marx arrives at the assumption of 'the universal and exclusive domination of capitalist production'. ${ }^{31}$ This theoretical simplification is, according to Marx, never effected in reality. 'In theory, we assume that the laws of the capitalist mode of production develop in their pure form. In reality, this is only an approximation; but the approximation is all the more exact, the more the capitalist mode of production is developed and the less it is adulterated by survivals of earlier economic conditions with which it is amalgamated. ${ }^{, 32}$

We have therefore shown how Marx, as a consequence of his problematic, necessarily had to make a whole series of simplifying assumptions, with the result that the complicated mechanism was reduced to the simple formula $c+v+s=C .{ }^{33}$ This aggregate of the real parts of profit in the common, general category of surplus value as such corresponds with an analogous aggregate of the real parts of capital (industrial, interest-bearing, merchant's capital, etc.) in

31 Marx 1978, p. 422.

32 Marx 1981, p. 275. [Grossman's emphasis.] The methodologically extremely important conception of the paths that lead to the imposition of capitalism's distinctive laws, that Marx developed here, is directly counterposed to the view held by Luxemburg. According to her, the existence of pure capitalism without non-capitalist purchasers is impossible. According to Marx's conception, non-capitalist producers simply constitute the remnants of earlier economic formations, which contaminate the effect of the pure laws of the capitalist mode of production. Pure capitalism is not only possible, according to Marx, but its laws become all the purer the more these obscuring remnants of earlier formations disappear.

33 [Where $\mathrm{c}$ is constant capital, v variable capital, s surplus value, and $\mathrm{C}$ the total value of commodities produced.] 
the common, general category of capital as such. Just as the path, once taken, had forced Marx to turn his gaze away from material to function, it also led him from the superficial, visible, partial appearances of profit and the various forms of capital to his powerful vision of the totality of aggregate surplus value and aggregate capital. A Contribution to the Critique of Political Economy in six parts simply becomes Capital and the metamorphoses of its circuit!

Marx attributed the utmost theoretical importance to the reduction of all empirically given forms of earnings without labour, like profit, interest, ground rent, etc., to 'the simple, fundamental form'. ${ }^{34}$

The best points in my book are ... 2. the treatment of surplus value regardless of its particular forms as profit, interest, ground rent, etc. This will be made clear in the second volume especially. The treatment of the particular forms in classical political economy, where they are forever being jumbled up together with the general form, is an olla potrida. $^{35}$

And in a further letter to Engels of 8 January 1868, Marx reproached Dühring for not detecting the book's 'fundamental element' in his review of Capital: 'That in contrast to all previous political economy, which from the outset treated the particular fragments of surplus value with their fixed forms of rent, profit and interest as already given, I begin by dealing with the general form of surplus value, in which all these elements are still undifferentiated, in solution as it were. ${ }^{36}$

In order to understand the whole meaning of the short formula just mentioned, one must remember that, in his analysis of the problem of equilibrium under capitalism, Ricardo neglected this essential element of the capitalist mode of production, the capital relation. He does not take the fundamental contradiction, capitalist class-working class, as the starting point of his analysis. Instead, he tries to understand and solve the problem by using the example of independent producers. Sismondi accuses him of abstracting from this class relation, the necessary characteristic of capitalist production. 'There is perhaps no other method of reasoning that is open to more errors than that of constructing a hypothetical world altogether different from the real one. ${ }^{37}$ Methodological simplifications must not go too far, i.e. they must not disregard the essential elements of the object of investigation as Ricardo does. 'To my mind the abstraction ... is too strong ... this is no simplification, this is

35 Marx 1987d, p. 407. [Olla potrida is a highly spiced Spanish dish with very diverse ingredients, literally 'rotten pot'. Here it means a hodgepodge, with particularly negative connotations.]

36 Marx 1987e, p. 514.

37 Sismondi 1991, p. 603. [Grossman's emphasis.] 
misleading us by hiding from our view all the successive operations by which we can distinguish truth from error. ${ }^{38}$ And, indeed, wherever it is a matter of understanding the fundamental evil associated with capitalism, one needs to start with the class of wage labourers. 'We will look at society in its actual organisation, with workers without property ... because it is precisely this social arrangement to which our objections apply. ${ }^{39}$

If the characteristic feature of capitalism is the capital relation, the specific relation between entrepreneurs and wage labourers, then every Robinsonade is methodologically excluded from the analysis from the outset. This applies both to the primordial Ricardian hunter with his bow and to Thünen's 'tropical country' in its still undeveloped, pre-capitalist state, where the fundamental class division between entrepreneur and wage labourer does not yet exist and to where, according to Thünen's assumption, 'a people with all the skills, knowledge and craft of the civilised European nations' was relocated. And although this country 'possesses no capital and thus no tools', ${ }^{40}$ according to Thünen, the laws governing capitalism, the laws of capital accumulation, interest and wages should be investigated and defined among the people living there, isolated in the tropics, without capital and without a working class!

The significance of Marx's formula is much greater than the aspect [Moment] just mentioned. In fact, Marx's procedure was an important advance over the classicals because it alone made the exact formulation and proof of the law of the tendency for the rate of profit to fall possible. The movements of the empirically visible parts of income without labour temporarily and for specific parts of surplus value run counter to the general tendency of the movement (or, as it is put today, the 'secular trend line') of surplus value in the course of capital accumulation, as 'the simple, fundamental form of the process of accumulation is obscured both by the splitting-up of surplus value and by the mediating movement of circulation. ${ }^{41}$ All those who see only the partial movements of surplus value, e.g. the large profits of individual branches of production and not the relations of society as a whole, like e.g. Charasoff, therefore dispute the fact of the fall in the rate of profit: the law of the tendency for the rate of profit to fall is apparently a mistake. $^{42}$

The law itself, however, is a self-evident consequence of the labour theory of value if accumulation takes place on the basis of a progressively higher organic

38 Sismondi 1991, p. 621. Cf. also Grossman 1924, p. 114.

39 Sismondi 1991, p. 621.

40 Thünen 1921, p. 486.

41 Marx 1976b, p. 710.

42 Cf. Grossmann 1992, p. 50. [Georg Charasoff was a forerunner of mathematical neo-Ricardian economic theory and the author of Charasoff 1910.] 
composition of capital. 'The fall in the rate of profit thus expresses the falling ratio between surplus value itself and the total capital advanced; it is therefore independent of any distribution of this surplus value we may care to make among the various categories. ${ }^{43}$ And, in fact, if one starts with the formula $c+v+s[=C]$ and supposes a yearly increase of constant capital c of $10 \%$ and of variable capital $v$ of $5 \%$, it follows simply and clearly that, with accumulation and as a consequence of the rising organic composition of capital, once a certain level is reached, the tempo of accumulation becomes ever smaller, despite an initial acceleration, and accumulation eventually becomes impossible. The mass of surplus value is insufficient to sustain growth at the level required by the rapidly increasing constant capital.

$$
\begin{array}{lr}
1 & 200,000 c+100,000 v+100,000 s \\
2 & 1,000,000 c+100,000 v+110,000 s \\
3 & 4,600,000 c+100,000 v+120,000 s
\end{array}
$$

In the first case, constant capital c can be accumulated at $50 \%{ }^{44}$ of its initial size, if surplus value is used solely for the purposes of accumulation. In the second case, with a significantly higher organic composition of capital and even though the rate of surplus value has grown, the expanded mass of surplus value of 110,000 s barely suffices to increase the initial capital by $10 \%$. Finally, in the third case, a mass of surplus value of 120,000 barely increases the initial capital by $2 \frac{1}{2} \%$. It is easy to calculate that, as the organic composition of capital rises more, a point must come when it is impossible for accumulation to continue. That is Marx's law of breakdown - 'the absolute general law of capitalist accumulation'. ${ }^{45}$ Its discovery was possible thanks to the analysis of the actual movement of surplus value, by means of the aggregation of the empirical parts of surplus value into the category of surplus value, that is only on the basis of the formula $c+v+s$ $[=\mathrm{C}]^{46}$

43 Marx 1981, p. 320. [Grossman's emphasis.]

44 [The original has ' $40 \%$ ', which is presumably a typographical error.]

45 Marx 1976b, p. 798.

46 Marx's theory of breakdown and his famous 'negation of negation', had been regarded as merely 'pitfalls of the Hegelian dialectical method' [Bernstein 1993, pp. 29-31] and the product of a residual Hegelian dialectic of contradictions, corresponding to Hegel's three-part schema of development. This was because the fact that the law of breakdown is a necessary result of accumulation on the basis of the progressively higher organic composition of capital and therefore the 'real movement' arises from the analysis of real phenomena [Erscheinungsstoff] had been overlooked. With regard to this law, therefore, what Marx says about the distinction between the method of presentation and the method of inquiry holds especially true: 'Inquiry ... has to appropriate the material in detail, to analyse its different forms of development and to track down their inner connection. Only after this work has been done can the real movement be appropriately presented. If this is done successfully, if the life of the subject-matter is now reflected back in the ideas, then it may appear as if we have before us an a priori construction', Marx 1976b, p. 102) [Grossman's emphasis]. 
The classicals, who only pursued the empirically given parts of surplus value in their particular movements, 'suspected' the law without, however, being able to formulate it. According to Marx, this law constitutes 'the mystery around whose solution the whole of political economy since Adam Smith revolves and that the difference between the various schools since Smith consists in the different attempts made to solve it.' Hence, Marx correctly says

Simple as the law appears ... not one of the previous writers on economics succeeded in discovering it. These economists perceived the phenomenon, but tortured themselves with their contradictory attempts to explain it ... If we consider, on the other hand ... how it [previous political economy] has never presented surplus value as something separate from profit, nor profit in general, in its pure form, as distinct from the various constituents of profit which have attained an autonomous position towards each other (such as industrial profit, commercial profit, interest, ground rent) ... then it ceases to be a puzzle that political economy has never found this puzzle's solution. ${ }^{47}$

In this account, which places the law of the tendency for the rate of profit to fall at the centre of all scientific efforts in the field of political economy since Smith, Marx links the possibility of discovering this law, which is of course identical with Marx's law of accumulation and breakdown, with the methodological simplification and condensation of the capitalist mode of production into the formula $c+v+s[=C]$. The fundamental idea of Marx's economic system and at the same time the central axis of the capitalist economy around which all scientific efforts since Smith turn is, according to Marx's own assessment, most intimately connected with the construction of the formula.

But, from the standpoint of Marx's formulation of the question, is the problem of leading the analysis back to the fundamental capital relation, to the formula $c+v+s[=C]$, specified with sufficient exactitude? Was the series of simplifications exhausted? Or could and should still others have been made - and which? How far could the simplification go, which elements should not be abstracted away under any circumstances? As we have seen, Sismondi had already posed this question. With regard to the procedure of simplification, Hegel correctly said: 'It must be observed that in this very process of scientific understanding, it is of importance that the essential should be distinguished and brought into relief in contrast with the so-called non-essential. But in order to render this possible, we must know what is essential. ${ }^{48}$

47 Marx 1981, pp. 319-20. [Grossman's emphasis.]

48 Hegel 1991, p. 65. 
In fact, for Marx there was no doubt about the essence of capitalism. He had to recognise it before he began to present his system, even before he wrote the first page of his work. The reduction of the capitalist mode of production to the fundamental capital relation still did not exhaust the number of its necessary premises, according to Marx. That is to say, the capital relation only forms one necessary fundamental premise and condition for capitalism. According to the formula $\mathrm{c}+\mathrm{v}+\mathrm{s}=\mathrm{C}$, we are only dealing with a single firm; hence any commodity exchange and hence commodity production itself is impossible. The second fundamental condition of the capitalist mode of production, commodity exchange, is not taken into account. ${ }^{49}$ For 'only the products of mutually independent acts of labour, performed in isolation, can confront each other as commodities. ${ }^{50}$ Where these conditions do not apply, commodity production, hence also capitalist commodity production, is out of the question. '[T] consider society as a single subject is wrong; a speculative approach. ${ }^{51}$ Where no commodity exchange exists, there can also be no question of commodity production, hence, of capitalist commodity production. As Marx also wanted to express commodity exchange as a necessary prerequisite for the capitalist mode of production in his formula, he necessarily had to give an account of not one capitalist, but at least two independent commodity producers or groups of producers, who mutually exchange their products and hence only then demonstrate their commodity character. If one does that, then instead of the formula $c+v+s=C$ one obtains the following

$$
\begin{array}{ll}
\text { I } & c+v+s=c \\
\text { II } & c+v+s=C
\end{array}
$$

In this way, the parameters for the construction of Marx's schema were given, and we have shown, step by step, the chain of thought that necessarily led from Marx's problematic to this result. Now, however, if the schema is to reflect the capitalist mode of production, another element must be included in its parameters. For at the present level in the development of our thought it has merely been established that commodity exchange is a necessary, fundamental premise of all capitalist production; that therefore the schematic simplification must necessarily depict at least two groups of producers in enduring exchange relationships. But here another question arises: is this a matter of any two arbitrary branches of production, e.g. coal mines and steelworks? Or does the formulation of the problem here not also entail certain necessary fundamental conditions

49 Cf. Grossmann 1929a, p. 607.

50 Marx 1976b, p. 132. [Grossman's emphasis.]

51 Marx 1986, p. 31. [Grossman's emphasis.] 
for the formation of the exchange relationships between the two branches of production? With this question we arrive at the problem posed by Rosa Luxemburg as the central point in the discussion of whether a capitalism conceived of as isolated could possibly exist and her thesis that a 'gap' exists in Marx's analysis of the reproduction and accumulation process.

We saw earlier that Marx had to exclude all foreign trade relationships from his analysis of capitalist surplus-value production - not only with non-capitalist, but also with foreign capitalist countries - in order to measure the magnitude of surplus value that could be obtained by a given social capital. Now if it is true that Marx thus excluded one of the necessary conditions for reproduction on an expanded scale - sale to non-capitalist purchasers - from his analysis; that he demonstrated the conditions for the production of surplus value, but not the possibility of its realisation, of its sale; that, consequently, there exists a 'gap' in his account because only the process of production was shown, but not the possibility of sales, then on-going reproduction as a continuous process appears impossible.

Rosa Luxemburg tried to strengthen her theoretical critique of Marx's analysis by pointing out 'that the second volume is not a finished whole but a manuscript that stops short half way through. ${ }^{52}$ Certainly a convenient method of theoretical argument. Unable to find a way out of the dead-end in which one has landed, one declares there is a 'gap' in the system. On the issue of accumulation, Marx had not, in particular, gone further than specifying certain schemas and their initial analysis. ${ }^{53}$ Luxemburg refers to the incomplete character of the second volume of Capital, but she forgets that, while the schematic representation of the reproduction process was only carried out in the second volume, the essential aspects of Marx's theory of reproduction and accumulation are developed in the first volume, which we have in a finished form. Furthermore, it is false to claim that the specification of the reproduction schema in the second volume 'stops short halfway through'. In fact, it was already conceptualised in 1863, before the publication of the first volume of Capital, and it underlies the whole analysis of the first volume as well as the other volumes of Marx's principal work (and not merely the chapter on reproduction in the second volume). Luxemburg overlooks how, in the chapter on accumulation in the first volume, Marx had already anticipated the essential results of the theory of reproduction and accumulation, substantiated in detail in the second volume. 
In light of these facts, it is absolutely unacceptable to claim that Marx did not go beyond the specification of certain schemas and their initial analysis. On the contrary, we have attempted to demonstrate that the reproduction schema does not merely underlie the final part of the second volume, that it is not merely important for the question of the complete sale of commodities, but that the plan for the whole work is intimately connected with the methodological conception of the reproduction schema. The construction of all three volumes of Capital was carried out methodologically on the basis of the meticulously thought-out and actually implemented procedure of successive approximation [Annäherungsverfahren], which, logically, is inseparably connected with the reproduction schema. Each provisional simplification correlates with a later, corresponding concretisation. In my book The Law of Accumulation and Breakdown (Chapter 3), I have shown that Marx's procedure of subsequent concretisation was actually carried out meticulously. So there can be no question of a 'gap' resulting from his method of simplification. Despite all the simplifying assumptions, Marx never went so far in his procedure as to abstract from the capital relationship or from commodity exchange between the two spheres of production, I and II, because both elements constitute necessary conditions for capitalist production. If Marx excluded foreign markets from his analysis of the process of reproduction this did not occur, therefore, because there is an accidental 'gap' in his account, but because the relations of foreign trade do not belong to the theoretically necessary conditions for the process of reproduction. If Marx had considered the 'realisation' of surplus value in non-capitalist countries a necessary condition for accumulation, his reproduction schema would have looked quite different, namely

\section{The capital relation (capitalist $\mathrm{c}+\mathrm{v}+\mathrm{s}$ country): \\ II Non-capitalist country: independent producers}

In this schema, department I would not merely encompass the production of means of production, but would undifferentiatedly encompass the whole production of the capitalist country. For, once non-capitalist markets are included in the reproduction schema, what purpose would the well-known division of the branches of production according to the use-values of the commodities they produce serve? What purpose would the demand for definite relations of proportionality in the size of these two branches of the production apparatus serve in the capitalist country? Even if such relations of proportionality do not exist - e.g. if the capitalist country only encompasses a single department and e.g. only produces means of production, and thus there 
is no possibility of selling its $v+s$ parts on the domestic market of the capitalist country, reproduction and accumulation can nevertheless continue without interruption because the sale of the $v+s$ parts can occur in foreign, non-capitalist countries. From these, on the other hand, means of consumption for workers and capitalists can be obtained through foreign trade. The division of the apparatus of production in the capitalist country into the two well-known departments - I (production of means of production) and II (production of means of consumption) - has no purpose in such a case.

If Marx combines capitalist production not into one, but into two branches of production - and not into any arbitrary branches, but in such a way that means of production must necessarily be produced in one, and means of consumption in the other - then this occurs because, in his schema, Marx wanted to illustrate all the necessary conditions for the existence of a capitalism that is conceived of as isolated. If, in capitalism conceived of as isolated, only means of production are produced, then means of consumption must be obtained from abroad if reproduction is to be conceived of as a continuous process. Conversely, if only means of consumption are produced, then the importation of means of production is unavoidable. In this way, foreign trade relations would be a necessary condition for the reproduction process as a whole. Yet, for the reasons identified above, Marx excludes foreign trade relations from his schematic analysis! If the schema of capitalist production constructed by Marx excludes foreign trade relations and is not to be an unrealistic phantom, Marx had to ensure in other ways that the schema includes all the elements that are significant, i.e. vital for the capitalist mode of production. By explaining that the division of the apparatus of production in the capitalist country was a necessary condition for equilibrium and allowing for the production of means of production and means of consumption, Marx seeks to construct a mechanism of production independent of foreign trade relations that is nevertheless viable and self-contained. Only in a capitalism thought of in this way does it make any sense to inquire about the relations of proportionality necessary for equilibrium, i.e. for the complete sale of all commodities on the domestic market. Only in this case do these relations of proportionality constitute a necessary condition for a course of reproduction free from disruption. Including non-capitalist markets in the schema destroys the schema's fundamental theoretical idea, the proof of the necessity of definite relations of proportionality. Thus it invalidates the real content and great significance of Marx's discovery! 
Now we want to compare the results of our general analysis of the theoretical conditions of Marx's procedure in the schema, as they arose from the general requirements of Marx's problematic, with Marx's concrete presentation of the conditions for reproduction.

The process of accumulation and reproduction is dealt with first not in the second volume of Capital, but already in the twenty-fourth chapter of the first volume, where the 'transformation of surplus value into capital' is presented. ${ }^{54}$ Here was the systematic place and opportunity to mention the role of noncapitalist markets, if in Marx's conception they had constituted a necessary condition for the transformation of surplus value into capital; if Marx considered 'pure' capitalism impossible. This even more, because in the first volume Marx had already investigated not only the conditions for accumulation from the standpoint of the individual capital, but, in the twenty-fifth chapter, also developed 'the general law of capitalist accumulation' and the 'continual re-conversion of surplus value into capital' ${ }^{55} \mathrm{He}$ had the social conditions for accumulation in mind and, in relation to them, formulated a series of social laws, such as e.g. the law of concentration and centralisation of capital, the capitalist mode of production's distinctive law of population and the emergence of the reserve army of labour as a product of accumulation and a condition for its sudden expansion, and finally the necessary breakdown of the capitalist mode of production. Here Marx further enumerates a series of aspects, which 'determine the extent of accumulation' ${ }^{56}$ Marx did not mention non-capitalist purchasers as a condition for accumulation! And this is supposed to be an accidental 'gap' in his account?

And further! Marx already avails himself of a series of simplifying assumptions in his presentation of accumulation in the first volume. What was the purpose of these methodological simplifications, of this abstraction from a series of empirically given aspects? Marx's explanations are so clear as to be scarcely controversial: in his analysis of the problem of accumulation, Marx wants to abstract from all aspects that are incidental to the problem of accumulation, even if they are otherwise important, in order to highlight all the more starkly the essential, fundamental conditions for the accumulation process. In the presentation of the accumulation of surplus value, i.e. its transformation into capital, Marx has to demonstrate 'the necessary conditions 
under which it [surplus value] becomes an element in accumulation. ${ }^{, 57}$ This, then, is the purpose of Marx's simplifications! Everything but the 'necessary conditions' should be abstracted away. The analysis only deals with 'the simple, fundamental form of the process of accumulation ... An exact analysis of the process, therefore, demands that we should, for a time, disregard all phenomena that conceal the workings of its inner mechanism'. ${ }^{58}$ If Marx considered the 'realisation' of surplus value in non-capitalist markets a necessary condition for accumulation, it would be impossible for him to refrain from including the function of non-capitalist markets in his analysis of the conditions for accumulation. Marx would have, rather, to demonstrate this here because, according to this conception, it would constitute a necessary part of the 'inner workings' of the capitalist mechanism, its 'simple, fundamental form'. Instead of Marx's current schema, we would have had a different one, namely

$\begin{array}{ll}\text { II independent producers } & \mathrm{c}+\mathrm{v}+\mathrm{s}\end{array}$

The basic fact that Marx did not do this, that he explicitly abstracted from foreign trade altogether, thus also from foreign trade with non-capitalist countries, and even counts it among 'disturbing subsidiary circumstances', which disguise the inner workings of the mechanism 'in its purity', ${ }^{59}$ proves the opposite of Luxemburg's claim. It proves that Marx believed that a capitalism conceived of as isolated, without external markets, was possible and he was convinced that the fundamental laws of accumulation were more sharply expressed without the 'disturbing influences' of foreign trade. Finally, it proves that one cannot speak of a 'gap' with regard to Marx's deliberate exclusion of foreign markets! The 'gap theory' is nothing other than a comfortable little cloak, which disguises the fact that Luxemburg, under the pretext of ostensible 'further development' and 'gap filling', actually, on this essential point of the structure of Marx's thought, abandoned and combated his theory of accumulation!

That one cannot speak of a 'gap' in Marx's work at this point can be precisely demonstrated by a further argument. In the chapter on accumulation, Marx considers it necessary not merely to present the conditions for accumulation positively, but to critically polemicise against the 'political economists' erroneous conception of reproduction on an increasing scale'. ${ }^{60}$ Never and

57 Marx 1976b, p. 710. [Grossman's interpolation. 'Necessary' is in the original German text, Marx 1991, p. 506, but not the Penguin translation.]

58 Marx 1976b, p. 710. [Grossman's emphasis.]

59 Marx 1976b, pp. 269, 727.

60 Marx 1976b, p. 734 
nowhere, however, had they considered the necessity of non-capitalist countries as a condition of accumulation. Was it not the best opportunity, indeed a logical requirement, to demonstrate their theoretical 'mistakes' and to point out the necessary function of non-capitalist countries precisely here? But one does not find a trace of this in Marx. The same Marx who refutes the erroneous conception of accumulation of bourgeois economics, namely that of Smith, and uncovers Smith's 'stupid blunder'61 which claims that surplus value in accumulation 'is laid out exclusively in the payment of wages'. ${ }^{62}$ The same Marx who in the chapter mentioned above polemicises against the iron law of wages and further against the theory of compensation in relation to workers displaced. ${ }^{63}$ Would this Marx have silently ignored that other theory of all previous economics, that accumulation without non-capitalist markets, that 'pure' capitalism is possible? That would be highly unlikely for another reason. Engels mentions in the Preface to the second volume of Capital that 'It is sufficient to enumerate the manuscript material that Marx left to show the incomparable conscientiousness and severe self-criticism with which he strove to bring his great economic discoveries to the utmost degree of perfection. ${ }^{64}$ In fact, we know that all the more important problems are mentioned by Marx at different points in his work three, four and often more times, and Marx never missed the opportunity to point out the errors of his predecessors. To give just one example: the 'erroneous conception of increasing accumulation' on the part of bourgeois economics, namely that of Smith, mentioned above, is already refuted in the first volume, ${ }^{65}$ and then combated again in the third part of the second volume. ${ }^{66}$ Finally, for the third and fourth times, Marx deals extensively with this problem in his critical analysis in Theories of Surplus Value. ${ }^{67}$ The same is true for a series of other problems. Would it not be odd, then, that Marx should repeatedly uncover all the errors of bourgeois economics, but fail to mention, even with one syllable, in any place in his works and manuscripts over a period of thirty years, the cardinal error that a capitalism conceived of as isolated, without a non-capitalist 'milieu', is possible?

The previous indications suffice to license us to conclude that the convenient 'torso' - or 'gap' theory - that takes the path of least resistance is absolutely

61 Marx 1978, p. 449.

62 Marx 1976b, p. 737

63 [Marx 1976b, on the possibility of higher wages, pp. 768-772; against compensation theory, 'that all machinery that displaces workers simultaneously, and necessarily, sets free an amount of capital adequate to employ precisely those workers displaced', pp. 565-75.]

64 Marx 1978, p. 84.

65 Marx 1976b, pp. 734, 736. [Grossman is paraphrasing Marx's words, already quoted above, rather than quoting them.] 
insupportable, and that it must be discarded once and for all. ${ }^{68}$ Rather, it is imperative for the analysis of Marx, in all theoretical respects to start with the opposite, basic premise: that the material left to us by Marx is essentially finished, apart from the details of exposition. Consequently, when dealing with difficulties that arise for the problematic of the individual partial areas and partial theories of Marx's system, the highest principle must be that the difficulties are to be overcome not by means of mechanical, superficial additions and completions but within the given material, in accordance with the logic of the system as a whole. This means nothing more than that one must hold to the idea that Marxist economics, as it has been bequeathed to us, is not a 'fragment' or a 'torso', but constitutes a finished, i.e. complete, system.

In constructing his schema to present only the 'necessary conditions', the essential, fundamental form of the process of reproduction and accumulation, Marx had to know what was essential about capitalist production in order to separate it from the non-essential, to use Hegel's language. Marx already has these essential, fundamental conditions in mind when he approaches the composition of Capital, the presentation of the first chapter of his work. In the first chapters of the first volume, Marx is already concerned not with immediately given empirical appearances, not with profit, interest, ground rent, etc., but with their ideal aggregate, with surplus value. He is not concerned with the empirically given appearance of price, but starts with the fictitious premise that commodities are sold at their values, which includes further assumptions: that the apparatus of production is in a state of equilibrium; that

68 This also applies to Georg Lukács, who advocates the 'fragment' theory criticised here and who rejects the conception that 'Marx's formulae were arrived at on the basis of a hypothetical society (posited for reasons of method) which consisted only of capitalists and workers.' On the contrary, L. emphasises 'that Marx posited this society for the sake of argument, i.e. to see the problem more clearly, before pressing forward to the larger question of the place of this problem within society as a whole.' Up to this point, we can agree with L. His mistake lies in his view that Marx himself never completed this task. That is, Marx - to use Marx's language - made the journey from the conception of the concrete totality, from the 'conception of the whole' analytically, by means of simplifying methodological assumptions, until he arrived at 'more and more tenuous abstractions', i.e. to an abstract capitalist society, which consists only of capitalists and workers, without foreign trade. But that he did not retrace the journey back to a concrete 'rich totality of many determinations and relations', to the 'living whole'. [Marx 1986, p. 37]. According to L., the result is 'that on this issue Capital is an incomplete fragment which stops short at the point where this problem should be opened up. In this sense what Rosa Luxemburg has done is precisely to take up the thread where Marx left off and to solve the problem in his spirit' (Lukács 1971, p. 31). Elsewhere Lukács writes of Rosa Luxemburg's 'admirable extension of Marx's theory of capitalist reproduction' (Lukács 1970, p. 41). In my book, The Law of Accumulation and Breakdown, I have shown that Lukács's assertion is incorrect and indicated 'that in the methodological construction of the system each of the several fictitious, simplifying assumptions is subsequently modified.' 'These considerations mean that the abstract analysis comes closer to the world of real appearances', Grossmann 1992, pp. 30 and 131. 
the commodity labour power is likewise sold at its value; that no reserve army exists; and, finally, that no competition takes place. In short, Marx already had all the simplifying assumptions of his reproduction schema in mind before he even wrote the first page of his work or could write it.

It is certainly one of the greatest misunderstandings and distortions of Marx's thought to associate Marx's reproduction schema with only the last chapter of the second volume of Capital, with only the problem of the complete sale of the year's product; and finally, to see only the simplifying assumptions, but not the subsequent corrections. As was shown here, Marx's reproduction schema is intimately connected with the methodological procedure that underlies all three volumes of Capital. For this reason, the change in the plan for Marx's life's work and the construction of the reproduction schema arose from the same fundamental idea. Marx's method is, in its general principles, the true expression of his formulation of the problem. Only in relation to the latter can the real reasons for it also be understood.

Translated from the German by Geoffrey McCormack Edited and annotated by Rick Kuhn

\section{References}

Bernstein, Eduard 1993 [1899], The Preconditions of Socialism, edited and translated by Henry Tudor, Cambridge: Cambridge University Press.

Charasoff, Georg 1910, Das System des Marxismus: Darstellung und Kritik, Berlin: H. Bondy.

Engels, Friedrich 1978 [1884], 'Preface', in Marx 1978.

Grossman, Henryk 1924, Simonde de Sismondi et ses théories économiques: une nouvelle interprétation de sa pensée, Warsaw: Bibliotheca Universitatis Liberae Polonae.

Grossmann, Henryk 1929a, Das Akkumulations- und Zusammenbruchsgetz des kapitalistischen Systems (zugleich eine Krisentheorie), Leipzig: Hirschfeld.

— 1929b, 'Die Änderung des ursprünglichen Aufbauplans des Marxschen Kapital und ihre Ursachen', Archiv für die Geschichte des Sozialismus und der Arbeiterbewegung, 14: 305-38.

1992 [1929], The Law of Accumulation and Breakdown of the Capitalist System: Being also a Theory of Crises, translated and abridged by Jairus Banaji, London: Pluto Press.

Hegel, Georg Wilhelm Friedrich 1991 [1840], The Philosophy of History, Amherst: Prometheus Books.

Kautsky, Karl 1897, 'Vorwort', in Marx 1897.

1921 [1887], Karl Marx' Ökonomische Lehren, Stuttgart: J.H.W. Dietz.

Lukács, Georg 1970 [1924], Lenin: a Study on the Unity of His Thought, translated by Nicholas Jacobs, London: New Left Books.

1971 [1923], History and Class Consciousness: Studies in Marxist Dialectics, translated by Rodney Livingstone, London: Merlin.

Luxemburg, Rosa 1951 [1913], The Accumulation of Capital, translated by Agnes Schwarzschild, London: Routledge and Kegan Paul. 
1972 [1921], The Accumulation of Capital - An Anti-Critique, in Rosa Luxemburg and Nikolai Bukharin, Imperialism and the Accumulation of Capital, edited by Kenneth J. Tarbuck, London: Allen Lane.

Marx, Karl 1897, Zur Kritik der Politischen Oekonomie, Stuttgart: J.H.W. Dietz.

— 1904, A Contribution to the Critique of Political Economy, translated by N.I. Stone, Chicago: Charles H. Kerr \& Company.

— 1976a [1847], The Poverty of Philosophy: Answer to the Philosophy of Poverty by M. Proudhon, in Marx and Engels Collected Works, Volume 6, New York: International Publishers.

_ 1976b [1867], Capital: A Critique of Political Economy. Volume 1, translated by Ben Fowkes, Harmondsworth: Penguin.

1978 [1885], Capital: A Critique of Political Economy. Volume 2, translated by David Fernbach, Harmondsworth: Penguin.

1981 [1894], Capital: A Critique of Political Economy. Volume 3, translated by David Fernbach, Harmondsworth: Penguin.

— 1985a, 'Letter from Karl Marx to Ludwig Kugelmann, 28 December 1862', in Marx and Engels Collected Works, Volume 41, New York: International Publishers.

— 1985b, 'Letter from Karl Marx to Frederick Engels, 6 July 1863', in Marx and Engels Collected Works, Volume 41, New York: International Publishers.

— 1985c, 'Letter from Karl Marx to Engels, 15 August 1863', in Marx and Engels Collected Works, Volume 41, New York: International Publishers.

1986 [1903, written 1857] 'Introduction', in Marx and Engels Collected Works, Volume 28, New York: International Publishers.

— 1987a [1859], A Contribution to the Critique of Political Economy. Part One, in Marx and Engels Collected Works, Volume 29, New York: International Publishers.

— 1987b, 'Letter from Karl Marx to Ludwig Kugelmann, 29 November 1864', in Marx and Engels Collected Works, Volume 42, New York: International Publishers.

_ 1987c, 'Letter from Karl Marx to Ludwig Kugelmann, 13 October 1866', in Marx and Engels Collected Works, Volume 42, New York: International Publishers.

— 1987d, 'Letter from Marx to Engels, 24 August 1867', in Marx and Engels Collected Works, Volume 42, New York: International Publishers.

— 1987e, 'Letter from Marx to Engels, 8 January 1868', in Marx and Engels Collected Works, Volume 42, New York: International Publishers.

_ 1987f, 'Letter from Karl Marx to Friedrich Engels, 30 April 1868', in Marx and Engels Collected Works, Volume 43, New York: International Publishers.

— 1989a [1905], 'Economic Manuscript of 1861-63' [Notebooks VII to XII], in Marx and Engels Collected Works, Volume 31, New York: International Publishers.

_ 1989b [1905], 'Economic Manuscript of 1861-63' [Notebooks XII to XV], in Marx and Engels Collected Works, Volume 32, New York: International Publishers.

1991 [1890], Das Kapital: Kritik der Politischen Ökonomie. Erster Band, Fourth Edition, in Marx-EngelsGesamtausgabe, Division II, Volume 10, Berlin: Akademie Verlag.

Marx, Karl and Friedrich Engels 1927-41, Historisch-kritische Gesamtausgabe, Frankfurt am Main and Berlin: Marx-Engels-Archiv, Verlagsgenossenschaft ausländischer Arbeiter in der UdSSR and Marx-Engels-Verlag.

Sismondi, J.-C.-L. Simonde de 1991 [1819], New Principles of Political Economy: Of Wealth in Its Relation to Population, translated and annotated by Richard Hyse, London: Transaction Publishers.

Stone, Nahum Isaac 1904, 'Preface', in Marx 1904.

Thünen, Johann Heinrich von 1921 [1842], Der isolirte Staat in Beziehung auf Landwirthschaft und NationalÖkonomie, Jena: Fischer.

Wilbrandt, Robert 1920 [1918], Karl Marx: Versuch einer Würdigung, Leipzig: B.G. Teubner. 